\title{
The impact of the Pensions Regulator
}

Received: 11th May, 2005

\section{David Norgrove}

was appointed as first chairman of the Pensions Regulator in January 2005. His career, spanning both the public and private sectors, began at the Treasury as an economist. His time there included two years on secondment to the First National Bank of Chicago, and he was Private Secretary to Prime Minister Margaret Thatcher from 1985 to 1988 . He joined Marks \& Spencer in 1988, was appointed to the board in 2000 and was chairman of the pension fund trustees from 2000 until his retirement in 2004.

Abstract The Pensions Regulator, the new regulator of work-based pension schemes in the UK, has wider powers than its predecessor and a new proactive and risk-focused approach to regulation. This paper sets out its statutory objectives, describes how they will be achieved and comments on the principal aim of empowering pension scheme trustees.

Keywords: pensions; work-based; regulation; funding; proactive; risk-based

\section{A little history}

The Pensions Regulator which replaced Opra on 6th April this year is not just a makeover job but a fundamentally new organisation. Opra was a creation of the Pensions Act 1995, a piece of legislation drawn up with the aim of preventing another Maxwell scandal. In contrast, the Pensions Regulator is a creation of the Pensions Act 2004 which seeks to simplify and make more effective the requirements of the earlier Act, but also to deal with the catastrophe of underfunded final salary schemes forced into winding up following the insolvency of the sponsoring employer.

Alan Pickering's call for a 'new kind of regulator', the publication of Opra's first quinquennial review and the National Audit Office's report all drew much the same conclusions. They noted that Opra's able staff were flooded with large numbers of reports on late payments of contributions, the overwhelming majority of which were of no material significance at all. Opra reacted to the reports it received but had limited scope to be proactive. It lacked adequate information about the schemes which it regulated and, most tellingly, its powers were too limited in relation to events driven by a combination of employer insolvency and scheme deficits.

\section{The impact of the new regulator}

The Pensions Regulator is fortunate in that the 2004 Act sets it some primary objectives, a strong recommendation made in the earlier reviews. They are:

- to protect the benefits provided to members of work-based pension schemes;

- to reduce the risk of situations arising which may lead to compensation being payable from the Pension Protection Fund; and 
- to promote and to improve the understanding of the good administration of work-based pension arrangements.

These are useful and concrete objectives and they represent the Pensions

Regulator's mission statement. To achieve them the Regulator must be able to gather information, identify problems and then take action. This paper will look first at the impact of the new regulator stemming from the need to gather information.

\section{Scheme returns}

Section 72 of the 2004 Act gives the Pensions Regulator power to require pension schemes to send us scheme returns - a power not given to Opra. This process has begun, using pro-forma questionnaires which are being sent to some 8,000 defined benefit (DB) schemes. This will be an annual process for the largest schemes but smaller schemes will be asked to update their information less frequently. The information supplied on these returns will be the basis for the calculation of the risk-based protection levy. This data therefore serves a key purpose. The Pensions Regulator will also publish summaries and an analysis of the returns so that all those working on pensions policy can be better informed by having access to reliable data.

\section{Notifiable events}

Information on DB schemes will also come from the notifiable events regime introduced by s 69 of the Act. Trustees and employers are required to tell the Pensions Regulator when certain events occur which are relevant either to the funding or governance position of the scheme; are relevant to the employer's solvency; or the strength of the employer's covenant with the scheme. The notifiable events regime should provide an early warning of potential claims on the Pension Protection Fund. Given that early warning, the Pensions Regulator hopes to be able to intervene and take action to prevent this from happening. Two good examples of notifiable events are a decision by the trustees to compromise a debt owed to the scheme and the downgrading of the employer's credit rating from investment grade to sub-investment grade.

\section{Reporting breaches}

The statutory 'whistleblowing' duties set by the Pensions Act 1995 fell just on the scheme actuary and the scheme auditor. Such a duty to report a breach of the law has been extended by the 2004 Act so that all of the following are covered:

- the trustees or managers of an occupational or personal pension scheme;

- any person who is otherwise involved in the administration of such a scheme;

- any employer participating in an occupational pension scheme;

- professional advisers in relation to such a scheme; and

- any person who is otherwise involved in advising the trustees or managers of an occupational or personal pension scheme in relation to that scheme.

Opra's famous 'traffic light' system will continue to be operated, so that potential reporters are clear that only in circumstances where they have reasonable cause to believe that the breach is likely to be of material significance should they contact the Pensions Regulator. Opra was inundated with reports of relatively trivial breaches, so the Regulator must be careful not to 
send out the wrong signal and dissuade anyone from making what might prove to be a vital report.

\section{Identifying problems}

Identifying a problem essentially involves carrying out a risk assessment. It is the general intention that the impact of the Pensions Regulator on the pension schemes that it regulates should be low in cases where its assessment is that the schemes present a low-risk profile.

Schemes, however, with a high-risk profile are likely to notice that the Pensions Regulator is having a greater impact and it can be guessed that the trustees and sponsoring employers may not always like that.

The move to a regulator taking a risk-based approach inevitably involves that regulator also taking risks. Since we are a creature of the legislation, that risk is also borne by the government of the day. At various points, some unforeseen risks are bound to materialise and to that extent the Pensions Regulator will have failed to meet one or more of its statutory objectives. When a scheme has been identified as presenting a comparable high risk the Pensions Regulator will be proactive and enter into a dialogue with the trustees and employer. An approach will therefore be adopted which is both risk-based and proactive. Intervention will be proportionate, but that proportionality will be based on the risk being run.

The Pensions Regulator will carry out its risk assessment using both its judgment and computer scoring. Risk assessment will be influenced in relation to schemes covered by the Pension Protection Fund by the amount of the risk-based levy that such a scheme will be required to pay. Yet it must be emphasised that other factors will also come into play - after all, funding to the level of Pension Protection Fund protection is not the same thing as full funding!

\section{Taking action}

The Pensions Act 2004, subject to any amendments made in the Act, has transferred to the Pensions Regulator all the powers formerly conferred on Opra by the Pension Schemes Act 1993, the Pensions Act 1995 and the Welfare Reform and Pensions Act 1999. Yet the 2004 Act has also given the Pensions Regulator a number of important new powers such as:

- improvement notices;

- third party notices;

- freezing orders;

- financial support directions;

- contribution notices; and

- restoration orders.

All 44 of those powers that are known as 'the reserved regulatory functions' are listed in Schedule 2 of the 2004 Act. But it is important to understand the process under which any of those particular key powers will be exercised.

The 2004 Act sets up an important body known as the Determinations Panel. The process involves the executive of the Pensions Regulator having to make an individual case to the Determinations Panel. The Panel's job is then to make not only the decision on whether such a power should be exercised but also, where it decides that it should, to exercise that power in its own name.

The author has appointed John Scampion as chair of the Determination Panel. He is a Commissioner member of the Healthcare Commission, a member of the Criminal Injuries Compensation Appeals Panel and a former metropolitan 
local authority CEO. He in turn has nominated the seven other members:

- Duncan Campbell, recently appointed to the chair of the disciplinary sub-committee of the Banking Code Standards Board and legal adviser at the CBI;

- Geoffrey Fitchew, former chairman of the Building Society Commission and former European Commission director general for financial institutions and company law;

- Michael Maunsell, former managing partner of Lovell, White and Durrant solicitors;

- Dianne Hayter, vice-chairman of the Financial Services Consumer Panel and board member of the National Consumer Council since 2001;

- Suzanne McCarthy, former CEO of the Financial Services Compensation Scheme;

- Olivia Dickson, former senior adviser to the Financial Services Authority and also former managing director of JP Morgan; and

- Daniel Taylor, former company solicitor for News International Newspapers Limited.

This is a formidable line up. It is this body of men and women who will decide, for example, if a contribution notice or a financial support direction is to be made. This will provide reassurance that the decision to exercise any key powers will not fall to a young, inexperienced yet enthusiastic junior member of staff?

\section{Empowering trustees}

Unless there is an immediate risk to members' benefits, the Pensions

Regulator will not present a case to the Determinations Panel for the exercise of any of the reserved statutory functions until it has completely run out of patience with discussion and negotiation with the employer and trustees involved. In as much as its regulatory role over occupational pension schemes is being discussed here, the reason that the Pensions Regulator, as a matter of policy, will not immediately reach for its powers is that it would risk undermining one very important aim, which is to empower trustees in their relationship with the employer.

As Justice Knox pointed out in the case of Hillsdown Holdings $v$ the Pensions Ombudsman, it is perfectly proper for trustees to negotiate with the employer provided both have a legitimate interest to preserve. With the advent of the scheme specific funding rules for DB schemes and the specific requirement in most cases for the trustees to obtain the employer's consent to, for example, any provisions of a recovery plan, these negotiating skills will have to become well-developed. This will not be helped, however, if the Pensions Regulator tries to micro-manage from the centre by issuing countless orders and directions.

\section{Keeping employers in business}

Nor will it help fulfil its key objectives of protecting the benefits of members of occupational pension schemes, or of reducing the risk of situations arising which may lead to compensation being paid from the Pension Protection Fund, if the Pensions Regulator presses for a recovery plan that involves a high risk of causing the sponsoring employer to become insolvent. Insolvent companies can no more pay contributions than can unemployed scheme members.

The Pensions Regulator has already been faced with more than one case where the employer would certainly become insolvent if it could not walk away from its final salary scheme, with 
the result that the Pension Protection Fund will have to pick up the cost of meeting the proportion of the protected liabilities that cannot be met by the remaining assets in the pension scheme. The approach taken by the Pensions Regulator in such situations has been to agree that a new company could be created without the pension scheme (which would then fall into the Pension Protection Fund) so that employment of the active members can be maintained. But it insists that this should be conditional on:

- the pension scheme (and so ultimately the Pension Protection Fund) benefiting from any recovery by giving the trustees a stake, short of control, in the new company;

- the trustees not compromising the debt on the employer under the Pensions Act 1995; and

- the arrangement not breaching the restriction on employer related investments.

Where no new money is going into the new company, the trustees' stake will be larger in situations than where investments are going in from the banks or other investors.

Have no doubt that the Pensions Regulator will act when it believes that employers are deliberately trying to avoid their pension obligations. If there is an attempt to avoid a statutory debt, the Pensions Regulator will, if necessary, issue a contribution notice requiring payment for those involved. If there is a transaction at undervalue involving the scheme's assets, it can issue a restoration order.

There is no intention to interfere with the normal business activity of any employer. Already, requests are being received for clearance statements in relation to potential contribution notices arising from actions to avoid employer debt, or to potential financial support directions in relation to under-resourced service companies. The Pensions Regulator has already received a steady stream of requests for clearance statements, but so far it has not been swamped! 